\title{
WHEN THE CHECKPOINT BECOMES A \\ COUNTERPOINT: STASIS AS QUEER DISSENT
}

\section{QUANDO O PONTO DE CHECAGEM SE TORNA UM CONTRAPONTO: ESTASE COMO DISSIDÊNCIA QUEER}

\author{
Tommaso M. Milani ${ }^{*}$ \\ Muzna Awayed-Bishara* \\ Roey J. Gafter ${ }^{* *}$ \\ Erez Levon ${ }^{* * *}$
}

\begin{abstract}
This article was born out of a sense of discomfort with the privilege accorded to movement and mobility in critical scholarship in the social sciences and the humanities, including critical work on the relationship between language, sexuality and space. It is our contention in this article that stasis can be deployed as a radical practice of defiance, and therefore can be queer too. In order to argue that stillness can be a form of social action carrying the potential of forging a radical politics of dissent, we take as a case in point the checkpoint in the context of Israel/Palestine. Drawing upon Said's $(1984,1994)$ notion of the counterpoint and Stroud's (2018) theorisation of linguistic citizenship, we illustrate how the checkpoint can become a bodily, discursive and material counterpoint that activates the irreconcilable tensions between utopia and dystopia in the pursuit of "thorough resistance to regimes of the normal" (WARNER, 1993, p. xxvi).
\end{abstract}

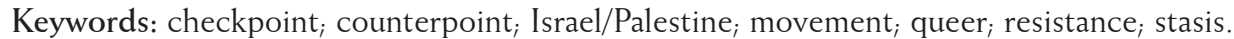

\section{RESUMO}

Este artigo nasceu de um sentimento de desconforto com o privilégio concedido ao movimento e à mobilidade nas abordagens críticas das ciências sociais e humanas, incluindo o trabalho crítico sobre a relação entre linguagem, sexualidade e espaço. É nossa opinião neste artigo que a estase pode ser utilizada como uma prática radical de rebeldia, e por isso também pode ser queer. A fim de argumentar que a imobilidade pode ser uma forma de ação social portadora do potencial de forjar uma política radical de dissidência, tomamos como

\footnotetext{
* University of Gothenburg, Suécia. tommaso.milani@gu.se

Orcid: https://orcid.org/0000-0002-7237-5501

** Hebrew University of Jerusalem, Israel.muznabishara@gmail.com

Orcid: https://orcid.org/0000-0003-4092-3582

*** Ben-Gurion University of the Negev, Berseba, Israel. roeyg@bgu.ac.il

Orcid: https://orcid.org/0000-0001-7261-0447

**** University of Bern, Suiça. erez.levon@csls.unibe.ch

Orcid: https://orcid.org/0000-0003-1060-7060

The title of this paper has been inspired by the headline of the programme of the Palestinian Youth Orchestra's European Tour "From checkpoint to counterpoint"
} 
exemplo o ponto de checagem no contexto de Israel/Palestina. Com base na noção de Said (1984, 1994) do contraponto e na teorização de Stroud (2018) de cidadania linguística, ilustramos como o ponto de checagem pode tornar-se um contraponto corporal, discursivo e material que ativa as tensões irreconciliáveis entre utopia e distopia na busca por "uma resistência profunda a regimes do normal" (WARNER, 1993, p. xxvi).

Palavras-chave: ponto de checagem; contraponto; Israel/Palestina; movimento; queer; resistência; estase.

\section{INTRODUCTION}

Over the last ten years, movement and mobility have become key signifiers that structure scholarship within the humanities and the social sciences. Applied linguistic research, in particular, has offered many nuanced analyses of the sociocultural, political and economic dimensions connected to the movement of people and to the circulation of material and symbolic resources, languages included (see e.g. BLOMMAERT, 2010, PENNYCOOK, 2012 and the research site Language on the Move [https:/www.languageonthemove.com] edited by Ingrid Piller to name just a few).

The theoretical relevance of the process of moving has also been foregrounded in current investigations that seek to understand the social and political role played by emotions in space (see e.g. BOCCAGNI, BALDASSAR, 2015, and the contributions to MILANI, RICHARDSON, in press). In this strand of inquiry, emotions are theorised less in terms of their ontological status - what they are - than for what they do, which include inter alia movement of and attachment to bodies. As Ahmed puts it,

Movement does not cut the body off from the 'where' of its inhabitance, but connects bodies to other bodies: attachment takes place through movement, through being moved by the proximity of others. (AHMED, 2014, p. 11)

The analytical import of movement for understanding the interface between bodies, emotions and space/place can be seen especially in the burgeoning field of geographies of sexuality. Understood in its twofold meaning of (1) passing in and/ or across space, and (2) a set of organised activities, movement has been employed as a conceptual tool through which to capture the spatial dynamics of sexuality, and its political implications. For example, geographer Gavin Brown proposes taking "a sense of movement seriously, not only studying queer as a social movement, but also tracing the movement of the concept 'queer' activism across time and space from its development in the metropolitan centres of North America" (BROWN, 2015, p. 73; see also MSIBI, 2014, BORBA, 2018 for insightful analyses of the 
travelling of gendered and sexual concepts across contexts). Also speaking from the disciplinary standpoint of geography but focusing on the Israeli context, Misgav and Hartal reiterate the "importance of researching the politics and spatial dimension of queer social movements, particularly within the urban context" (2019b, p. 4), which is also the rationale underpinning a recent special issue dedicated to the theme of Queer Urban Movements: Activism and Politics in Contemporary Contexts (MISGAV, HARTAL, 2019a).

In the light of these interdisciplinary insights, we do not dispute the heuristic potential offered by movement - queer movement in particular - in studying the relationship between language, power and resistance, which is the focus of this special issue. If applied linguistics is true to its aim of studying "real-world problems in which language is a central issue" (BRUMFIT, 1995, p. 27), it is imperative to investigate what more or less organised social actors do, and why, with a variety of semiotic resources (language, visual means, the body, music, etc.) when they move through spaces in the pursuit of a common political goal with regard to sexuality. Such an analytical focus on movement allows us to give granular accounts of the ways in which space is produced and made salient in individual and collective negotiations and contestations of sexual desires, identities and rights (see e.g. the contributions to MURRAY, 2014, MOTSCHENBACHER, 2020).

Yet we want to recast Biddy Martin's warning to "stop defining queerness as mobile and fluid in relation to what then gets construed as stagnant and ensnaring" (MARTIN, 1996, p. 46), and hence unqueer. While Martin's aim was to complexify overly facile oppositions between queer as fluid and transgressive, on the one hand, and what is presented as a more inert and "putatively puritanical feminism" (MARTIN, 1996, p. 46), on the other, our purpose is to trouble the very idea that for something to be queer it needs to be mobile. Of course, what counts as queer or not is a matter of debate not least because of queer scholars' long-standing defiance against fixing the term into a stable definition (see in particular BUTLER, 1993). With this caveat in mind, we believe that if there is anything distinctive about queer it is its antagonistic rejection of "a minoritising logic of toleration or simple political interest-representation in favour of a more thorough resistance to regimes of the normal" (WARNER, 1993, p. xxvi, emphasis added; see however WIEGMAN, WILSON, 2015, HALL, LEVON, MILANI, 2019 for critical perspectives on the relationship between queer and anti-normativity). It is our contention in this article that stasis can be deployed as such a radical practice of defiance, and therefore can be queer too. 
Arguing that stasis has political valence is nothing particularly new or earthshattering. After all, the act of stopping or slowing-down a variety of activities is at the very heart of labour strikes. However, we believe that it is important to recast the analytical relevance of stasis because it forces us to consider that movement is never fully unbounded. We are reluctant to give a definition of stasis that is applicable to all contexts. For us, stasis is inherently relational and works politically vis-à-vis movement: it indicates attempts to stop movement - both in terms of the circulation of bodies and discourses - or acts of refusal to move; it may also refer to those moments in which infrastructures that impede movement are strategically deployed to enact utopian "lines of flight" (DELEUZE, GUATTARI 1980) into a world that does not yet exist and to which we can only aspire.

In order to argue that stillness can be a form of social action carrying the potential of forging a radical politics of dissent, we take as a case in point the checkpoint in the context of Israel/Palestine (see WEIZMAN, 2007, RITCHIE, 2011). In this context the checkpoint "has become so omnipresent and intrusive that it has grown to govern the entire spectrum of Palestinian life under occupation" (WEIZMAN, 2007, p. 147). Without downplaying the real oppressive effects that the Israeli checkpoint system has on Palestinian bodies, we illustrate in this article how the checkpoint can be strategically turned on its head from a technology of movement reduction and control into a queer counterpoint, an instrument of sexual insubordination through which to speak back to Israeli pinkwashing (see the contextual section below for a discussion about pinkwashing).

For this purpose, we analyse three examples of sexual dissent in the context of Israel/Palestine: (1) a protest against Tel Aviv Pride parade enacted by a coalition of Israeli activists in 2017; (2) pronouncements about the parade on the part of different queer Palestinian activists and academics; and (3) a concert performed by the queer Palestinian artist Bashar Murad in the West Bank in 20191. Drawing upon Said's $(1984,1994)$ theoretical notion of the counterpoint, we illustrate the embodied, discursive and material shapes the checkpoint takes as a queer tactic of dissent, together with its spatial and affective dimensions. In fleshing out the relationship between sexuality, space and emotions, we also seek to bring fresh perspectives on current discussions about utopias, dystopias and the politics of affect in applied linguistics (see STROUD, 2018, OOSTENDORP, in press).

1. The examples in this article have been selected from a larger corpus of data that the authors of this article have collected individually and collectively in their work on language and the politics of sexuality in Israel/Palestine. 
In what follows, we first present an overview of the theoretical framework that informs this article; we then give a brief historical overview of sexual politics in Israel/Palestine, before delving into the analysis of three empirical examples of checkpoints.

\section{THE POLITICS OF CITIZENSHIP: COUNTERPOINTS AND THE UTOPIA/DYSTOPIA DYNAMICS}

The Palestinian postcolonial theorist Edward Said was an accomplished musician, and his writings are rich in musical terminology, imagery, and metaphor. Of these, the notion of the counterpoint is perhaps the most widely known, having played an influential role in textual, cultural, and socio-political analyses across a variety of disciplines. Originally formulated in the essay Reflections on Exile, the counterpoint offered Said a metaphor through which to describe his experience of forced dislocation which however opened up a "plurality of visions" and an "awareness of simultaneous dimensions" (SAID, 2000 [1984], p. 148). While "most people are principally aware of one culture, one setting, one home", Said wrote, "for an exile, habits of life, expression or activity in the new environment inevitably occur against the memory of these things in another environment. Thus, both the new and the old environments are vivid, actual, occurring together contrapuntally" (SAID, 2000 [1984], p. 148, emphasis added).

The analytical purchase of the counterpoint was clarified by Said ten years later in the book Culture and Imperialism in which he explained how:

In the counterpoint of Western classical music, various themes play off one another, with only a provisional privilege being given to any particular one; yet in the resulting polyphony there is concert and order, an organised interplay that derives from the themes, not from a rigorous melodic or formal principle outside the work. (SAID, 1994, p. 59-60)

Operationalised to critical academic practice, a contrapuntal reading typically "must take account [...] of imperialism and [...] resistance to it, which can be done by extending our reading of the texts to include what was once forcibly excluded" (SAID, 1994, p. 5). Conceptualised in this way, Said's contrapuntal reading could easily turn into what applied linguists have long warned against: "the celebration of bappy bybridity, as an unproblematic category of cultural diversity that somehow provides solutions to sociocultural relations and conflicts" (OTSUJI, PENNYCOOK 2010, p. 244, original emphasis). However, a contrapuntal reading does not aim "to valorise plurality" (CHOWDRY, 2007, p. 101) downplaying 
inequalities of power; rather it is an intellectual enterprise that refuses facile syntheses but pays attention to "the irreconcilable tensions among different elements, listening carefully to their voices" (MAGOME, 2006, p. 73, emphasis added).

Irreconcilable tensions are what we aim to unveil in the following analysis of instances of checkpoints. Granted, we do not want to romanticise the checkpoint, and the stasis associated with it, but to capture its twofold nature as a materialisation of imperialism and resistance to it, as Said (1994, p. 5) would say. More specifically, the examples below illustrate how checkpoints can become tools in the service of citizenship galvanising the irreconcilable tensions between utopia and dystopia in the pursuit of political enfranchisement. At this juncture, however, it is important to clarify what we mean by citizenship, utopia and dystopia.

In common parlance, citizenship is often equated or even conflated with nationality - the wielding of a passport that indicates an individual's legal membership in a particular nation-state (e.g. Brazil, Italy, Sweden, etc.). This is what political scientists would call citizenship as status: it indicates an existing social and legal contract that determines the rights and duties of an individual vis-à-vis the state (and vice versa). However, political theorist Engin Isin cautions that too strong emphasis on citizenship as status ultimately obscures the dynamics through which individuals internalise citizenship as a type of babitus, an unreflected way of thinking and acting, which takes shape in "routines, rituals, customs, norms and habits of the everyday" (ISIN, 2008, p. 17).

That citizenship is a set of norms and behaviours into which we are socialised does not mean that we cannot break with babitus, or act without having official status. Isin (2008) proposed acts of citizenship as a notion that captures those performances of radical dissent that go against the proverbial grain at the crossroads of what is considered legal and what is not. Isin has further developed his ideas, going on to rename "acts of citizenship" to "performative citizenship". The change of label is not a terminological triviality but is part of an argumentative move with analytical implications:

A performative perspective on citizenship enables researchers to study various acts of making rights claims in societies and states before, during, and after colonization without making prior assumptions about the presence or absence of that which might be called citizenship. (ISIN, 2017, p. 505)

In brief, performative citizenship grasps those moments in which individuals and/or groups stake political claims irrespective of their (il)legal status. Interestingly, such reflections within political theory are not dissimilar to Stroud's theorisation of linguistic citizenship, which he has developed in the field of applied linguistics over 
the last twenty years or so (see e.g. STROUD, 2001, 2009, 2018). Variation in labels notwithstanding, the two notions encapsulate parallel intellectual projects that seek to move away from a static view of citizenship to one that foregrounds the dynamic and agentive potential of the concept. There is a crucial distinction, though, in the understanding of politics that undergirds performative and linguistic citizenship, respectively. While for Isin (2017) politics is primarily a struggle about rights vis-à-vis the state, Stroud (2018) expands its meaning so as to encompass all acts through which people "position themselves agentively" and "craft new, emergent, subjectivities of political speakerhood, often outside of those prescribed or legitimated in institutional frameworks of the state" (STROUD, 2018, p. 4).

Through the emphasis on the political implications of speaking up more broadly, rather than a narrow focus on rights, Stroud (2018) seeks to shift the analytical and activist gear from "affirmative" to "transformative" strategies (FRASER, 1995). While the former "aim to correct inequitable outcomes of social arrangements without disturbing the underlying social structures that generates them" (FRASER, 1995, p. 82), the latter seeks to redress "unjust outcomes precisely by restructuring the underlying generative framework" (FRASER, 1995, p. 82$)$. And, as Stroud $(2018$, p. 23$)$ points out, a central component in the striving for transformation lies in the "utopian surplus" (ANDERSON, HOLDEN 2008) of performances of citizenship, their attempt to fundamentally reimagine and overhaul existing social arrangements, this being a quest that might never be achieved but is worth the effort nonetheless.

The utopian dimensions of linguistic citizenship have been studied thus far primarily in relation to issues of multilingualism and race in the Global South (see e.g. STROUD, 2015; MPENDUKANA, STROUD, 2019, OOSTENDORP, in press, ), rather than gender and sexuality. However, the utopian undercurrents of linguistic citizenship are in tune with queer theoretical imaginings of alternative sexual worlds. As Muñoz (2009) has pointed out, "utopia lets us imagine a space outside of heteronormativity... More importantly, utopia offers us a critique of the present, of what is, by casting a picture of what can and perbaps will be" (2009, p. 49). It should be clarified that utopia is employed here in its dual meaning of (1) a good place (from the Greek $e u$, good topos, place) and (2) of a place that does not yet exist (from Greek ou, non), but is worth striving for. What underpins these utopian perspectives on politics is reliance on hope as the affective resource par excellence that allows us to imagine and struggle for a better and fairer futurity (see in particular MUÑOZ, 2009; STROUD, WILLIAMS, 2017, STROUD, 2018; see also BORBA, 2019 for discussions about the politics of hope). 
While we agree on the relevance of hope for transformative purposes, Marcel reminds us that "the conditions that make it possible to hope are strictly the same as those that make it possible to despair" (MARCEL, 1965, p. 101). In other words, what enables utopias is also what buttresses their counterparts, dystopias (from dys: bad; topos: place) (OOSTENDORP, in press). The latter, "in pointing us towards the worst possible scenario, ... provide a warning from the future in our present" (SCOTT, BELL, 2016 in OOSTENDORP, in press). Crucially, while utopia and dystopia might be diametrically different prospective images of current conditions, they are nonetheless joined together by the same affective glue, bope. As Oostendorp clarifies, "hope is what makes utopia possible, and dystopias are what calls for hope" (OOSTENDORP, in press, p. 16). Put differently, there is always a looming dystopian ghost simultaneously threatening and catalysing the kind of agentive citizenship envisioned by Isin and Stroud. Or, read through a contrapuntal lens à la Said, there are always irreconcilable tensions between utopias and dystopias, and it is in these frictions that may lie the transformative potential of citizenship. Before analysing such productive tensions, we first want to give a brief contextual overview of the politics of sexuality in Israel/Palestine.

\section{HISTORICAL BACKGROUND - PINKWASHING AND HOMONATIONALISM FROM DIFFERENT SCALES}

Recent decades have seen various successful LGBT struggles for civil rights and recognition in various location marked by the co-opting of said rights into the national self-image, a discursive process which has been termed "homonationalism" (PUAR, 2007). As Puar explicates, the notion of "homonationalism" was created for "understanding the complexities of how 'acceptance' and 'tolerance' for gay and lesbian subjects have become a barometer by which the right to and capacity for national sovereignty is evaluated" (PUAR, 2013, p. 336). In other words, homonationalist discourse turns a Western understanding of LBGT rights into a litmus test for "progress", serving to exclude and delegitimise societies who are deemed homophobic and thus unworthy. While the term originated in reference to US politics in the context of increasing Islamophobia, a relevant critique of homonationalist discourse has been applied to Israel (GROSS, 2015, MILANI, LEVON, 2016, HARTAL, SASSON-LEVY, 2018).

From its inception, Israeli nationalism has always been characterised by an uneasy tension: while the claim to authentic roots in the Middle East underlies Zionist ideology, Israel also resisted a self-perception as nation fully integrated in 
the region, envisioning itself instead as a European "exclave" of sorts in the Middle East (SHOHAT, 1989). Indeed, a longstanding discourse in Israel celebrates "Israeli exceptionalism" and distinguishes it from its neighbouring countries, embodied for example in the popular slogan "the only democracy in the Middle East" (LEVON, GAFTER, 2019). Because Israel's level of LGBT protections policies are generally aligned with Western liberal values, a homonationalist discourse - framing Israel as more "modern" and "Western" than an Arab world portrayed as homophobic - can easily flourish as an extension of how Israeli nationalism is construed more broadly. Israel's relative acceptance of sexual diversity was readily morphed into a discursive strategy that excludes populations who are seen as less "tolerant" - that is, the Palestinians (MILANI, LEVON, 2016).

Israeli homonationalism manifests itself in the public arena in Israel's use of its perception as "gay friendly" to deflect criticism regarding its policies in the occupied Palestinian territories, a practice referred to as pinkwashing. Recent marketing efforts made by Israel to rebrand the city of Tel Aviv as a desirable destination for gay tourism have been extremely successful (MILANI, LEVON 2016). These efforts are characterised not only by top-down orchestrated municipal campaigns, but also by enthusiastic bottom-up participation by the local gay community (HARTAL, SASSON-LEVY, 2018). Nevertheless, although homonationalist discourse is prominent in Israeli gay circles, more subversive queer activism does exists alongside it (MILANI, LEVON, GAFTER, OR, 2018), and, as Misgav and Hartal (2019c) point out, "radical politics develops identifications with the most vulnerable sectors of the LGBT community... and produces new alliances with people and groups outside the LGBT community, such as Palestinians" (MISGAV, HARTAL, 2019c, p. 70). However, there is no agreement among queer Palestinians whether these alliances should be pursued at all.

Pivotal to our understanding of queer Palestinian agency in this study is the different living conditions and citizenry status of the Palestinians inside and outside the so-called Green Line ${ }^{2}$. While Palestinians outside the Green Line (or the West Bank) live under strict military occupation, Palestinians inside Israel, who constitute almost $20 \%$ of Israel's population, are discriminated against by a variety of laws, which ratify differential treatment with regard to several issues such as the right to acquire and lease land, the right of return, the right of residency (BISHARA, 2020).

2. The Green Line is the demarcation line that indicated the borders of Israel between the 1949 Armistice Agreements and the 1967 war. What is particularly relevant for the purpose of this paper is the spatial distinction between Israel and West Jerusalem (inside the Green Line), on the one hand, and East Jerusalem and the West Bank (outside of the Green Line), on the other. 
Following the establishment of Israel in 1948, Israeli citizenship was imposed on the Palestinians inside the Green Line who now constitute Israel's largest indigenous minority. Those who define themselves as "Palestinians" see themselves as the legitimate owners of the land, and the pursuers of a historical legacy of Palestinian struggle against Israel's military, land-confiscating, oppressive, and Zionist neocolonialist incursions inside and outside of the green line (AWAYED-BISHARA, 2020). The fact that Arab citizens also speak Arabic as their native language comprises another central component of their national identity. While Palestinians in Israel hold Israeli citizenship, and those outside the Green Line do not, Palestinian East Jerusalemites like the artist Bashar Murad (see section below) find themselves in somewhat of an impasse: they do not possess citizenship rights despite being born in a city under full Israeli control. Instead, they are rather trapped between permanent residency, whereby they "exercise only a limited set of rights but are able to live in Jerusalem, and statelessness, whereby their permanent residency is confiscated, their limited rights are revoked, and they are forced to leave the city in which they were born" (JEFFERIS, 2012, p. 203).

Within this very complex geopolitical context, queer politics is still generally hampered by sceptical voices to whom sexuality is viewed as either not relevant or not a priority for Palestinian liberation. Still, the work of alQaws ("the rainbow") for Sexual and Gender Diversity in Palestinian Society has added an essential element to the Palestinian struggle against Israel's settler colonialism. While alQaws has two of its main centres within the Green Line - i.e. in Haifa and Jaffa - two others lie outside of it, in East Jerusalem and Ramallah. Queering Palestine is among its most prominent goals which could be located in alQaws" vision to disrupt "sexual and gender-based oppression" and to challenge the "regulation of Palestinian sexualities and bodies, whether patriarchal, capitalist, or colonial" in order to build a society "that celebrates diverse sexualities, sexual orientations, and genders" (ALQAWS, 2014). And as we will see in more detail below, alQaws shuns any involvement with queer Israeli groups.

\section{THE MAKING OF A DYSTOPIA IN A "UTOPIA": THE POLITICS OF SHAMING AT TEL AVIV PRIDE}

Problematic as it may be, the branding of Tel Aviv as a gay haven has been extremely successful, attracting large numbers of 'pink' consumers from all over the world. Besides enjoying the pleasures of the sandy beaches and nightclubs of "the city that never sleeps" as Tel Aviv is often labelled in tourist promotional materials, 
gay tourists also contribute to boosting the numbers of participants in the yearly parade, and thereby help to build up the embodied manifestation of pride under the scorching Mediterranean sun. One could go as far as suggest that the branding campaign has successfully created an image of Tel Aviv as an accomplished utopia - a good place - for gay men, an urban "bubble", as the homonymous film directed by Eytan Fox calls it, in which gay male subjectivities can flourish.

In 2017, however, the bubble was momentarily punctured by a group of activists belonging to a variety of different organisations who teamed together to perform a protest against the yearly Pride parade. Standing behind a row of grey and pink panels with the slogan en gaava ba-kibuš ('there is no pride in occupation'), the demonstrators briefly stopped the incoming celebratory pageant before being pushed towards the sidewalks by the police and shouted at by the supporters of the right-wing party Likud (see also MAROM, 2017 for a media report on the event).

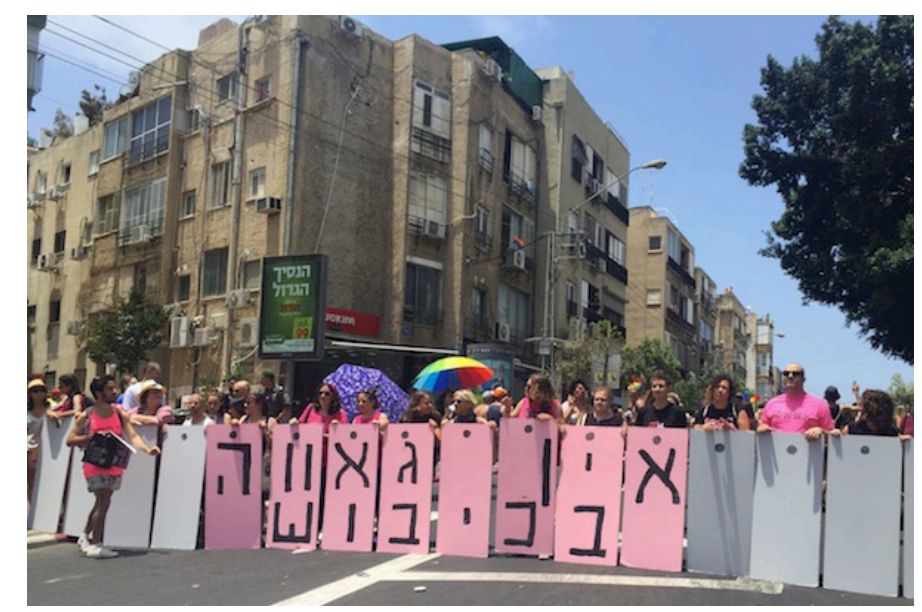

Figure 1. No pride in occupation Tel Aviv Pride 2017 @ Yael Marom

As can be seen in Figure 1 above, the combination of people's bodies, T-shirts, and cardboard panels, together with their "emplacement" (SCOLLON, SCOLLON, 2003) on the tarmac of central Tel Aviv, constitutes a complex spatial assemblage performing a multi-layered act of linguistic citizenship. To begin with, the content of the sign "there is no pride in occupation" draws upon the very affective resource that is at the heart of the parade - pride - in order to disavow it and activate its nemesis - shame. Notably, neither the slogan nor the shaming it produces is new but links intertextually the 2017 demonstration to the spatial disruptions performed by the left-wing queer Israeli groups Black Laundry (kvisa šxora) in the early 2000s and 
Mashpritzot in 2013. Therefore, in order to fully grasp the political significance of the slogan and its affective layers in the context of Israel/Palestine, we first need to give a brief excursus of the historical role played by shame in Israeli queer radical movements, which though small in numbers "have continuously protested the occupation and exhibited solidarity with Palestinians" (ATSHAN, 2020, p. 122).

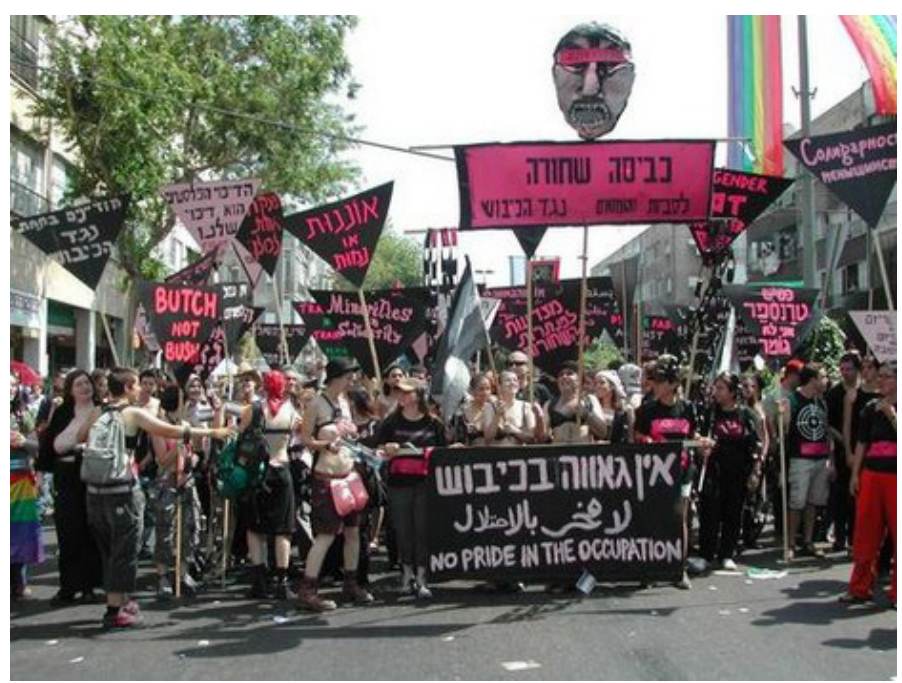

Figure 2. Black Laundry at Tel Aviv Pride 2002 @ Black Laundry

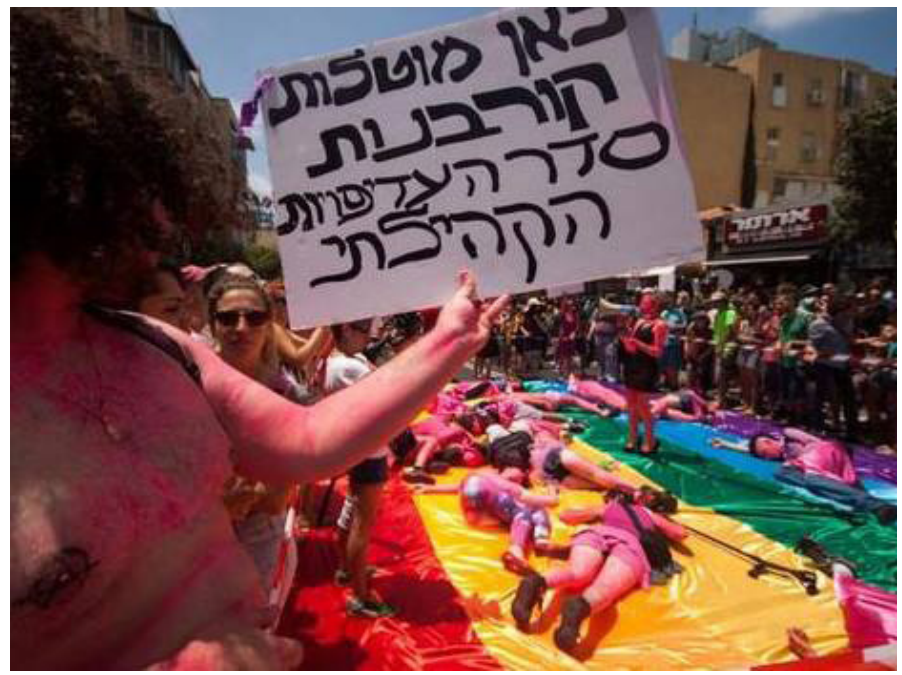

Figure 3. Mashpritzot's die-in at Tel Aviv Pride 2013 @ Mashpritzot 


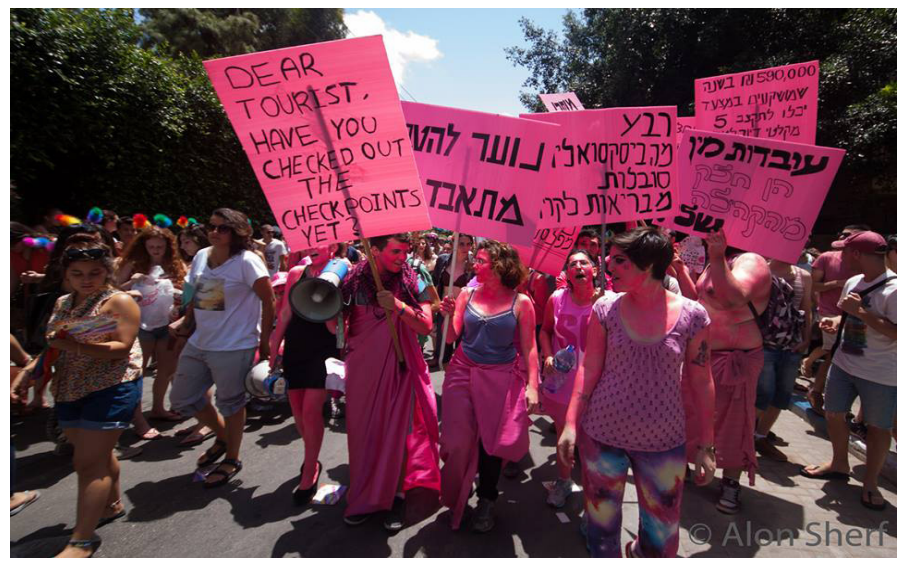

Figure 4. Mashpritzot's protest at Tel Aviv Pride 2013 @ Mashpritzot

That shame has been a key affective resource for radical queer Israeli groups is testified by the very name Black Laundry: it is a clever pun on the term "Black Sheep" (as the Hebrew word for "sheep", kivsa, is phonetically similar to "laundry", kvisa), and at the same time it also invokes the expression "dirty laundry", which is commonly used (in Hebrew as well as in Arabic and English) to refer to shameful secrets one rarely brings up in public (ZIV 2010, p. 537-538). Thus, the name encapsulates the essence of the group's activism: embracing their status as the proverbial black sheep of the "Israeli family" and airing out the dirty laundry that events such as the pride parade so desperately try to gloss over. As Ziv (2010) explains it, Black Laundry's protests (Figure 2) were built on "exaggerating and drawing attention to those very traits that have been a source of shame and social rejection (e.g., effeminacy in men or masculinity in women)" (2010, p. 547). Put differently, queer lived experiences of being shamed by heteronormative and homophobic practices and structures in Israeli society engendered an emotional alignment - empathy even - with the suffering experienced by Palestinians. Such an affective approximation led to the insight that "in the face of such violations [against Palestinians] it was impossible to keep one's sense of gay pride apart from one's sense of shame and accountability as an Israeli" (ZIV, 2010, p. 537). Most importantly for the purpose of this article, shame became like an affective boomerang which could be swung towards a different direction: queer Israelis resignified shame against them and repurposed it against the Israeli state.

The deployment of shame as a productive affective weapon in sexual protests in Israel can also be seen in a die-in performed by the group Mashpritzot during the Tel Aviv Pride parade in 2013 (Figure 3). This time the targets of critique were 
the priorities of Tel Aviv municipality vis-à-vis LGBTQ issues (see MILANI, 2019 for a detailed analysis of this protest). Among these is the allocation of 170,000 USD to the arrangement of the Pride Parade, a sum which according to Mashpritzot could instead have been spent to support five housing shelters. Tourists are also not exempt to being chastened. The question "Dear tourist, have you checked out the checkpoints yet?" sarcastically plays on a stereotypical image of gay travellers to Tel Aviv whose only preoccupation is partying in the "city that never sleeps", oblivious of, or indifferent to, the checkpoints to the West Bank and Gaza. Here the aim of the rhetorical question is to unsettle tourists' emotional investment in the Pride parade by shaming their apathy towards the Israel/Palestine conflict.

While Black Laundry and Mashpritzot thematised the Israeli occupation and its checkpoints in their slogans, the 2017 demonstration (Figure 1) actually recreated in the heart of Tel Aviv the very icon of the occupation: the Israeli West Bank Barrier. Also called Security Fence, Separation Wall or Wall of Apartheid, the barrier was built by the Israeli government in the wake of the second intifada, allegedly with "the sole purpose of saving the lives of the Israeli citizens who continue to be targeted by the terrorist campaign that began in 2000" (Israel Ministry of Defence). What should be highlighted for the purpose of this article is that, in erecting a human-size model of the wall, the demonstrators also enacted a checkpoint for the incoming parade. Unlike in previous protests, in which viewers were interpellated by slogans to engage with the checkpoint, here they are bodily confronted by its materiality. And it is this bodily/material dimension that produced affective and spatio-temporal effects of political import.

On an affective level, the demonstrators' wall functions as an affective checkpoint that seeks to slow down or even block the emotion that binds together the parade - pride. Analogous to the ways in which Black Laundry and Mashpritzot had strategically used shame as a boomerang that could be swung back to existing power arrangements, the 2017 protest employs the most iconic instrument of division between Israelis and Palestinians as an infrastructure through which to shame a mainstream, officially-sanctioned, and heavily marketed LGBT event in Israel. In doing so, they highlighted the need to connect different struggles despite group-specific interests. As Tanya Rubinstein, General Coordinator at Coalition of Women for Peace, explained in an interview with the progressive online magazine +972:

We came to the Tel Aviv Pride Parade, which the Israeli government uses to whitewash the crimes of the occupation, in order to remind everyone that the LGBTQ community's struggle is part of a larger struggle for freedom and human rights, and we cannot disconnect it from the struggle against separation walls and the continuing, systematic oppression of the occupation. 
This march does not belong to the police or the Tel Aviv municipality — it belongs to those who struggle for their rights, and thus it is a place where it is both fitting and necessary to protest and demonstrate. (MAROM, 2017)

Read through the lenses of Stroud's (2018) understanding of citizenship (see above), what the demonstrators did and said in relation to the Tel Aviv Pride parade can be taken as examples of "emergent, subjectivities of political speakerhood" with transformative aims. This is insofar as the reconstruction of the wall on the tarmac of central Tel Aviv laid bare "the underlying generative framework" (FRASER, 1995 , p. 82) of the Israeli occupation, which simultaneously fuels the marketing of Tel Aviv Pride and the disenfranchisement of Palestinians. In a similar way to how Black Laundry and Mashpritzot had previously turned the shame aimed at them on its head and redirected it towards the state and/or the Tel Aviv municipality, the protesters here re-designed the checkpoint against its architects: the state and those who are intentionally or not in collusion with it. Thus, it could be argued that the checkpoint was momentarily turned into a counterpoint, an infrastructure that simultaneously embodies "imperialism... and resistance to it", as Said would say.

In its twofold dimension of checkpoint/counterpoint, the bodily/material assemblage of demonstrators produced specific spatio-temporal effects of political relevance in relation to the parade and Tel Aviv more broadly. Perhaps most obviously, the bodily/material barrier enacted by the protesters blocked the incoming carnival, thus recreating a fleeting feeling of the more durable restriction of movement experienced by Palestinians, this time however for the jubilant participants. In doing so, the wall slowed down the euphoric rhythm of the parade - what Halberstam has called "queer time", the time of the festival, transient and contingent "unscripted by the conventions of family, inheritance, and child rearing" (HALBERSTAM, 2015, p. 2). While the happy-go-lucky time of the party conceptualised by Halberstam might indeed be "queer", i.e. anti-normative in certain contexts, one might wonder whether it has actually become normative in Tel Aviv, a city that is marketed as the gay party scene par excellence. In this context, it is perhaps the deceleration of time, stasis, that is anti-normative after all.

Moreover, as an act of linguistic citizenship, the bodily/material assemblage of the demonstrators relied on a productive tension between utopia and dystopia. Through the recreation of the Separation Wall, the gay utopia of the "city that never sleeps" was spatially and temporally confronted with the dystopia of the occupation with its concomitant slowing down of time and movement control. Dystopias have been typically theorised as imaginary worst-case scenarios that "provide a warning from the future in our present" (SCOTT, BELL, 2016 in OOSTENDORP, in press). 
In contrast, it is the cruel reality of the present that provided demonstrators with the material canvas from which their subjectivities of political speakerhood could come into relief, questioning the institutional frameworks of the Israeli state. Of course, we do not want to exaggerate and idealise the political relevance of the checkpoint performed by the 2017 demonstration. As Atshan argues, "queer liberation in Israel/ Palestine will be fully realised when anticolonial solidarity between queer Israelis and Palestinians is achieved". The 2017 demonstration could be viewed as a fleeting performance in that direction, albeit one that has not been unanimously endorsed by all constituencies that are critical of the Israeli occupation. It is to such critical voices that we will now turn.

\section{REPURPOSING THE CHECKPOINT IN PALESTINE: DEFIANCE, HOPE AND SUMUD}

Among the most vocal opponents of Tel Aviv Pride and Israeli pinkwashing is alQaws, a Palestinian NGO that defines itself on their website as:

a civil society organization founded in grassroots activism, is at the forefront of vibrant Palestinian cultural and social change, building LGBTQ communities and promoting new ideas about the role of gender and sexual diversity in political activism, civil society institutions, media, and everyday life.

Addressing specifically the celebration of Tel Aviv Pride in 2017, alQaws Director Haneen Maikey published an op-ed article in the widely read international weekly Newsweek in which she explained why Tel Aviv Pride should be boycotted. Makey opens her op-ed by offering a concise analysis of the relationship between the branding of Tel Aviv as a gay utopia and the occupation:

Gay Pride in Tel Aviv is heavily sponsored by the Israeli government and is cynically deployed to divert attention from the occupation of Palestinian lands and the daily violation of Palestinian rights.

What am I talking about? Well, the Israeli government has heavily invested in a "Brand Israel" propaganda campaign that uses cultural events and festivities to depict Israel's "prettier face" as a liberal, gay-friendly place. It does so to cover-up and maintain Israel's ongoing system of violence and racial discrimination, enshrined in dozens of laws against indigenous Palestinians, queers and non-queers alike. (MAIKEY, 2017)

Having set a problematic scene, she then goes on to interpellate readers inviting them to picture themselves what Palestinians' lived experiences are under Israeli occupation: 
Imagine living encircled by military checkpoints and a wall four times as long as the Berlin Wall, and in some places twice as high. Imagine this foreign power repeatedly using brutal force, including bombings and raids, to enforce its repressive rule. Imagine all this, and you'll get a glimpse of what Israeli military occupation has meant for millions of Palestinians. (MAIKEY, 2017)

Here the anaphoric usage of the imperative form of the verb "imagine", together with penetrating descriptions of the politics of maiming (PUAR, 2017), seek to bring into being specific spatial and affective stances in the reader: a sense of claustrophobia created by the wall compounded by the feeling of vulnerability that ensue from being simultaneously trapped and targeted by the Israeli military system.

Against this backdrop, Maikey concludes her op-ed with a succinct analysis of queer Palestinian struggle:

\footnotetext{
My work in the Palestinian queer movement has taught me that LGBTQI solidarity must never come at the expense of other emancipatory struggles, including the queer Palestinian struggle against institutional racial discrimination, which meets the U.N. definition of apartheid, and Israeli military occupation. I know that there is no pink door through Israel's illegal, racist wall that welcomes queer Palestinians while oppressing others.
}

My struggles intersect and cannot be separated. I reject the use of my queerness to erase other sites of oppression around me. (MAIKEY, 2017)

Taking an intersectional perspective that views discrimination as a set of mutually constitutive vectors of power, Maikey highlights the importance of sexual identity politics in Palestine ("LGBTQI solidarity"; "my queerness") at the same time as she distances herself from too optimistic reliance on it as a tool for empowerment. Echoing Fraser's (1995) warning against affirmative strategies of sexual identity politics (see above), Maikey ascribes to a transformative view according to which queer Palestinian enfranchisement will only be achieved once Israeli occupation is terminated.

Over the years alQaws has generated heated debates among academics and activists alike. It lies beyond the scope of this article to give an overview of the praises and critiques of alQaws's activism (see however ATSHAN, 2020 for a careful and insightful overview of the development of alQaws's strategies and media interventions over time). Suffice it to say that alQaws has swayed between an intersectional view of queer Palestinian empowerment as imbricated with the broader struggle for the liberation of Palestine, and more nationalist position according to which the fight against "Zionist colonialism....must be tackled before the group can have full conversations about sexuality". (Maikey in ATSHAN 2020, p. 59). 
On the basis of this, Atshan argues that "resistance to Zionism has increasingly taken priority over resistance to homophobia" (2020, p. 64). These fluctuations notwithstanding, alQaws has been adamant to emphasise the impossibility of joining forces with queer Israeli radical movements. The impossibility of a queer alliance between Palestinian and Israeli sexual activisms is encapsulated most forcefully in a Facebook post published by alQaws in the context of Tel Aviv Pride 2018.

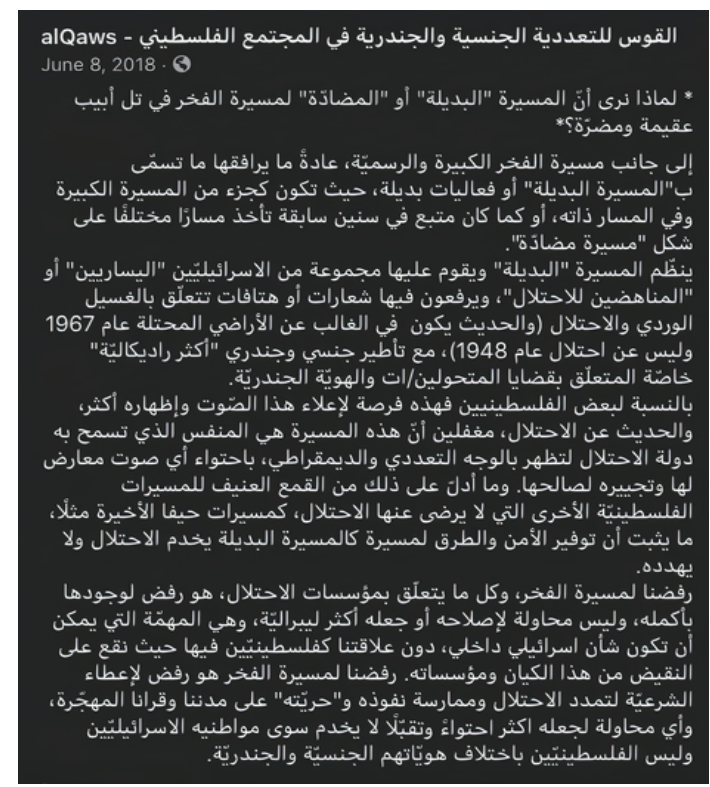

Figure 5. alQaws' Facebook post on Tel Aviv Pride 2018 @ alQaws

The so-called "alternative parade" or alternative activities often accompany the official and grand Pride Parade to an extent of becoming either a part of it and walking the same route, or as seen over the past years taking the form of a different "counter parade". [...]

For some Palestinians, this is an opportunity to raise this voice and make it more prominent, and for speaking about the occupation. What they miss out, however, is how this parade constitutes an access (loophole) which the state of the occupation approves in order to appear to the world in a democratic and pluralistic face through containing any contesting voice and bringing it to work for its benefits. [...]

Our rejection of the pride parade, and everything that has to do with the institutions of the occupation, is a rejection of its entire existence, and not an attempt to fix it or make it more liberal, which is a task that could be an internal Israeli matter and has nothing to do with us as Palestinians since we are at a counter position from both this entity and its institutions.

Our rejection of the pride parade is a refusal to grant legitimacy to the ongoing occupation and the exercise of its sovereignty and "freedom" over our cities and displaced villages, and 
any attempt to make it more containable or acceptable serves no one other than the Israeli, and not the Palestinian, citizens regardless of their different sexual and gender identities.

Unlike in 2017 when queer Israeli demonstrators tried to stop the Tel Aviv Pride Parade, in 2018 protestors against Israeli pinkwashing were actually part of the parade. Here the checkpoint/counterpoint dyad can be employed once again as a useful analytical tool through which to understand alQaws's act of linguistic citizenship, speaking up against queer Israeli activism. In saying so, we draw upon Ritchie's (2010) conceptualisation of the checkpoint "not just as a literal site on the border where agents of the state "inspect... what goes in and out" of the nation" but also as a broader metaphor that captures "a ubiquitous subjective process wherein citizens and noncitizens alike check themselves — and others - against "the field of signs and practices" in which the nation-state is represented" (RITCHIE, 2010, p. 557). Read in the light of such an expanded meaning, the act of linguistic citizenship performed by alQaws lies in erecting a discursive checkpoint against queer Israeli demonstrations and those Palestinians who are supportive of such protest acts.

For alQaws, embodied performances criticising the Tel Aviv Pride Parade and discursive pronouncements that welcome such interventions do not slow down or put a dent in pinkwashing and the Israeli occupation; rather they are acts of collusion with the very system they purport to condemn; they are instances of "affirmative strategies" (FRASER, 1995) that seek to ameliorate existing arrangements without challenging the very foundations upon which they rest. As an alternative, refusal to engage with the parade is proposed as the ultimate tactic of queer stasis, not only defying Israeli LGBTQ performances but also the underlying framework of the state that enables and markets them. This is because disavowal operates by bringing into being a discursive barrier that seeks to block "the field of signs and practices" of the Israeli state, and thereby severs the emotional and intellectual fuel supply to Tel Aviv Pride. Read with the help of Isin's (2008) breakdown of citizenship habitus and acts that go against habitus, one might say that AlQaws' acts of citizenship rupture habitus whereas the performances of radical protest groups at Tel Aviv Pride ultimately remain within an established habitus ${ }^{3}$. Put differently, as a discursive tactic, the checkpoint can become a contrapuntal strategy of critique that lays bare colonial structures at the same time as it performs defiance against them, pushing for a radical transformation of the status quo.

3. We are particularly grateful to one reviewer for this reading of our examples. 
Needless to say, not all queer Palestinians are in agreement with alQaws's discursive tactic of queer stasis. A diametrically opposite standpoint is taken by queer Palestinian academic and activist Sa'ed Atshan, who advocates that "the frontiers of queer liberation could be broadened by queer Palestinian organisations strategically partnering with queer Israeli institutions in the process of decolonization, coresistance to occupation and homophobia" (ATSHAN, 2020, p. 216). Such a coalition, in turn, is part of a larger "dream of queer Palestinians overcoming the surveillance and disenfranchisement - both discursive and embodied - that they face from many directions" (ATSHAN, 2020, p. 216). Espousing an intersectional approach to patterns of oppression, Atshan warns against downplaying normative practices that police gender and sexuality in Palestinian society. For him, however, taking a robust stance against heteropatriarchy in Palestine is not tantamount to embracing pro-Israeli pinkwashing. Instead, given that "the systems of Zionism and heteronormativity intersect", he advocates that "they need to be challenged simultaneously" (ATSHAN, 2020, p. 64, emphasis added).

An illustrative distillate of the simultaneous challenge to Israeli occupation and to heteronormativity can be found in the musical and intellectual work by queer Palestinian artist Bashar Murad. Born and raised in East Jerusalem in a family of musicians, Murad is a rising star on the international pop music scene. Among his most well-known pieces are the music videos الكل عم بتجوز (Everyone is getting married') in which he overtly challenges gender norms, and the bilingual Klefi / صامد ('resilience'), performed together with the Icelandic punk group Hatari and released shortly after the latter provocatively raised the Palestinian flag at the grand finale of the Eurovision Song Contest 2019 in Tel Aviv 4

Murad openly expressed the entanglement between the constricting forces of the occupation and gender/sexual normativity in an interview with the online music news site Reykjavik Grapevine in which he disclosed that:

\footnotetext{
Music was always an escape for me, an escape from the reality of living there. I grew up with two kinds of pressure: the pressure of occupation - the physical and emotional pressures of checkpoints, walls, curfews, constant military presence and soldiers always in your face pointing guns at you for no reason-and then the other kind of pressure, of living in a conservative society that is scared of anyone who's different. Being gay in that environment was very difficult. Music was the only way to escape it. I would write songs and sing for hours, it was like therapy for me. (Murad in FONTAIN, 2019).
}

4. Because of space constraints, we cannot delve into the details of the controversy around this specific arrangement of the popular song competition. However, Eurovision itself can be seen as part of the Brand Israel/pinkwashing project, and this is what Hatari sought to denounce with their act of flag-raising. 
Analogous to Maikey's description in the Newsweek article above, Murad's lived experience has dystopian tones, being caught in a vicious magnetic field in which the constraining and maiming forces of the Israeli occupation produce a claustrophobic sense of inescapable danger. This menace, in turn, is compounded by the no less pernicious forces of heteropatriarchy that police anything that goes against the gender and sexual grain. Read through the notion of the checkpoint, it could be argued that, for Murad, the Israeli-controlled barriers that enforce Palestinian movement control are tightly assembled together with the turnpikes of heteropatriarchy, constantly inspecting one's gender and sexual credentials.

Yet it was the concrete materiality of the checkpoint that became the locus from which Murad could accomplish a utopian act of linguistic citizenship. Performing on a stage built next to the Separation Wall at Aida Refugee Camp in Bethlehem, Murad sang a cover version of John Lennon's Imagine as part of Globalvision, an international alternative event that sought to critique the Eurovision Song Contest in Tel Aviv in 2019.

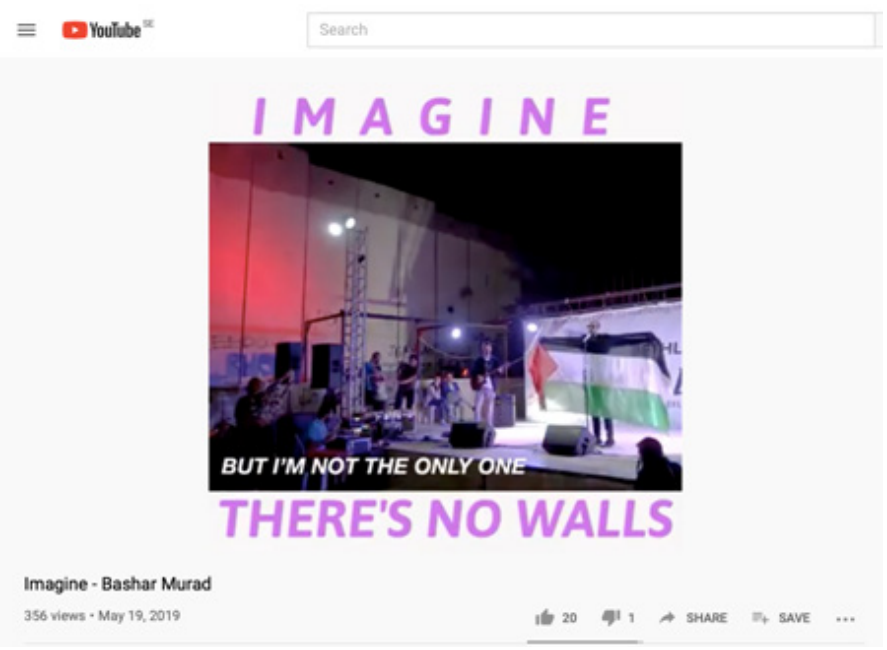

Figure 6. Screenshot of Bashar Murad's concert on Globalvision YouTube channel

Imagine there're no checkpoints

Now wouldn't that be cool

No need for permits or visas

And to hell with the wall too

Imagine all the people sharing all the world

You may say I'm a dreamer but I'm not the only one 
Hope someday you'll join us

And the world will live as one

Granted, the original version of Imagine has been slated by some music critics as an escapist hymn or as a white millionaire's hypocritical encouragement to envision a world without possessions, which he can propose while getting away from any criticism "because we are asked merely to imagine - to play a 'what if' game" (URISH, BIELEN, 2007). However, more compassionate readers have highlighted how the durable appeal of the song, especially in musical performances after tragic events, is due to the affective undertext of the lyrics:

the fact that the song persists, even though Lennon is gone, speaks to the enduring strength of his fantasy. If "Imagine" captures the fragility of our hope after a violent or destructive event, it also reveals its tenacity. (WALDMAN, 2015)

It is precisely hope and tenacity that Murad brings into being in his performance of Imagine, a song, which, as he put it, "echoes my sentiment of wanting people to unite regardless of their religion, ethnicity and sexual orientation". While in the examples above the checkpoint was either an assemblage of people and cardboards in Tel Aviv Pride or a discursive tactic seeking to block the discursive flow of Israeli pinkwashing, here the checkpoint is glaring in its magnitude of an eight-meter concrete barrier. What readers of Newsweek had been interpellated to picture themselves by Haneen Maikey (see extract above) is now presented bang on in its visual immediacy to the audiences of Globalvision.

As Walter Benjamin (1935) reminds us, the relationship between art and politics is always very complex, and it is often difficult to draw a clear line between (1) the aestheticisation of politics, which seeks to beautify unequal social conditions, leaving them unchanged, and (2) the politicisation of art, which deploys aesthetics in order to redress social inequalities. With this in mind, it could be argued that, as a backdrop of Murad's singing, the wall is aestheticised and made palatable to global audiences, thus contributing to the domestication of the occupation. Yet it could also be suggested that the semiotic assemblage of Murad's performance relies on a productive dissonance between the acoustic content of the message and the visual/material mis-en-scène of its enactment. The materiality of the wall next to the stage functions as an eerie counterpoint to the content of Murad's encouragement to imagine that there are no checkpoints, permit, visas or walls. And the jarring contrast between the acoustic and the visual can be taken as an enactment of a utopian "line of flight" (DELEUZE, GUATTARI 1980). Using the wall a canvas for his performance, Murad turns the stasis embodied in the wall into movement; 
he transforms the material reality of the checkpoint into a counterpoint in Said's understanding of the term: simultaneously a memento of the reality of the Palestinian present and a material vantage point from which to perform resistance, imagining the possibility of a completely different world.

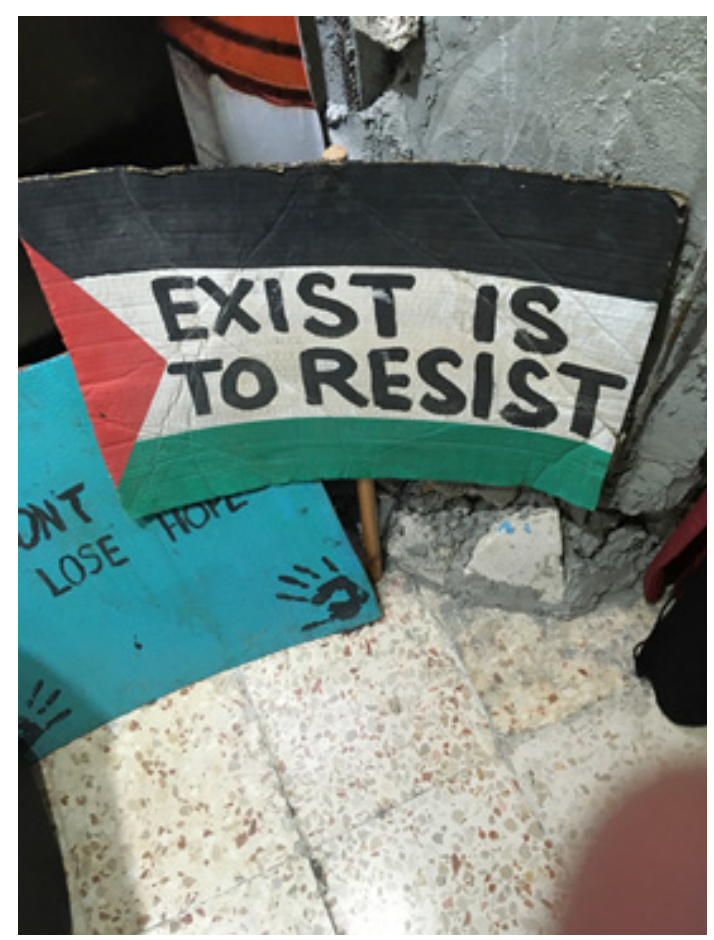

Figure 7. Sign taken at the museum at the Walled Off Hotel in Bethlehem (Photo taken by Tommaso Milani)

The fact that the performance took place at Aida Refugee Camp is particularly meaningful. Established in 1950 to host Palestinian refugees who fled or were forcefully pushed out of the newly established state of Israel, Aida has become a symbol of sumud, the steadfast perseverance of Palestinians, which is perhaps most powerfully encapsulated in the slogan on the sign above: for Palestinians, existence itself is an act of resistance. Stasis, staying put, refusing to move away despite all attempts on the part of the Israeli state to make Palestinian life unbearable at Aida is perhaps the queerest, most anti-normative, act of defiance after all. 


\section{CONCLUSIONS}

This article was born out of a sense of discomfort with the privilege accorded to movement and mobility in critical scholarship in the social sciences and the humanities, including critical work on the relationship between language, sexuality and space. We hope to have demonstrated that movement does not necessarily equal progress and subversiveness, nor is stillness inherently equivalent to stagnation and docility. Rather we need to see movement and stasis as imbricated in a contrapuntal dialectic. Drawing upon Said's $(1984,1994)$ notion of the counterpoint and Stroud's (2018) theorisation of linguistic citizenship, we have illustrated how the checkpoint can become a bodily, discursive and material counterpoint that activates the irreconcilable tensions between utopia and dystopia in the pursuit of "thorough resistance to regimes of the normal" (WARNER, 1993, p. xxvi). In the case of the Tel Aviv Pride parade, where the march itself has become a carnival which essentially endorses Israeli pinkwashing, the refusal of motion - either by blocking the flow of people or by rejecting to acknowledge it altogether - is a tactic of linguistic citizenship that queers the status quo. Moreover, even in the gloomy and pernicious reality of its material fabric, the Israeli Separation Wall can be productively employed as a backdrop from which to perform a utopian counterpoint, imagining a completely different future from within the harsh conditions of the present. Ultimately, our argument is that, as a counterpoint to movement, stasis can be an anti-normative practice of spatial meaning-making, and therefore can be queer too.

\section{REFERENCES}

AHMED, S. (2014). The Cultural Politics of Emotions. Edinburgh: Edinburgh University Press.

ALQAWS (2014). "About Us," http://www.alqaws.org/about-us.

ANDERSON, B.; HOLDEN, A. (2008). Affective urbanism and the event of hope. Space and Culture. v. 11, n ${ }^{\circ}$, pp. 142-159.

ATSHAN, S. (2020). Queering Palestine and the Empire of Critique. Stanford: Stanford University Press.

AWAYED-BISHARA, M. (2020). EFL Pedagogy as Cultural Practice: Textbooks, Practice, and Policy for Arabs and Jews in Israel. London, UK: Routledge. 
BENJAMIN, W. (1935). The Work of Art in the Age of Mechanical Reproduction. New York: Shocken.

BISHARA, A. (2020). Looking beyond the struggle for Palestinian statehood. Middle East Report, 294 (Spring 2020).

BLOMMAERT, J. (2010). The Sociolinguistics of Globalization. Cambridge: Cambridge University Press.

BOCCAGNI, P; BALDASSAR, L (2015). Emotions on the move: Mapping the emergent field of emotion and migration. Emotion, Space and Society. v. 16, pp. 73-80.

BORBA, R. (2017). Ex-centric textualities and rehearsed narratives at a gender identity clinic in Brazil: Challenging discursive colonization. Journal of Sociolinguistics. v. 21, $\mathrm{n}^{\circ}$ 3, pp. 305-464.

BORBA, R. (2019). Injurious signs: The geopolitics of hate and hope in the linguistic landscape of a political crisis. In: PECK, A.; STROUD, C.; WILLIAMS, Q. E. (eds), Making Sense of People and Place in Linguistic Landscapes. London: Bloomsbury, pp. 161-81.

BROWN, G. (2015). Queer movement. In: PATERNOTTE, D.; TREMBLAY, M. (eds.), The Ashgate Companion to Lesbian and Gay Activism. Aldershot: Ashgate, pp. 73-88.

BRUMFIT, C. (1995). Teacher professionalism and research. In: COOK, G.; SEIDLHOFER, B. (eds), Principle and Practice in Applied Linguistics: Studies in Honour of H.G. Widdowson. Oxford: Oxford University Press, pp. 27-41.

BUTLER, J. (1993). Bodies That Matter. New York: Routledge.

CHOWDRY, G. (2007). Edward Said and contrapuntal reading: Implications for critical interventions in International Relations. Millennium. v. 36, nº, pp. 101-116.

DELEUZE, G.; GUATTARI, F. (1988). A Thousand Plateaus. London: The Athlone Press.

FONTAIN, A. (2019). Queer musician Bashar Murad: "Just being Palestinian is political". The Reykjavik Grapevine $5^{\text {th }}$ June 2019. https:/grapevine.is/icelandic-culture/ music/2019/06/05/just-being-palestinian-is-political-queer-palestinian-musicianbashar-murad/

FRASER, N. (1995). From redistribution to recognition? Dilemmas of justice in a 'postsocialist' age. New Left Review. v. I/2012, pp. 68-93. 
GROSS, A. (2015). The politics of LGBT rights in Israel and beyond: Nationality, normativity, and queer politics. Columbia Human Rights Law Review, v. 46, n² 2, 81-152.

HALBERSTAM, J. (2015). In a Queer Time and Place: Transgender Bodies, Subcultural Lives. New York: NYU Press.

HALL, K.; LEVON, E.; MILANI, T. M. (2019). Navigating normativities: Gender and sexuality in text and talk. Language in Society. v. 48, $n^{\circ} 4$, pp. 481-489.

HARTAL, G.; SASSON-LEVY, O. (2018). Re-reading homonationalism: An Israeli spatial perspective. Journal of Homosexuality. v. 65, n 10, pp. 1391-1414.

ISIN, E. (2008). Theorizing acts of citizenship. In: ISIN, E. F.; NIELSEN, G. M. (eds), Acts of Citizenship. London: Zed Books, pp. 15-43.

ISIN, E. (2017). Performative citizenship. In: SHACHAR, A.; BAUBÖCK, R.; BLOEMRAAD, I.; VINK, M. (eds.), The Oxford Handbook of Citizenship. Oxford: Oxford University Press, pp. 500-523.

JEFFERIS, D. (2012). Institutionalizing Statelessness: The Revocation of Residency Rights of Palestinians in East Jerusalem. International Journal of Refugee Law, v. 24, nº 2, pp. 202-230.

LEVON, E.; GAFTER, R. (2019). "This is not Europe": Sexuality, ethnicity and the (re) enactment of Israeli authenticity. Discourse, Context and Media. v. 30, pp. 1-10.

MAGOME, K. (2006). Edward Said's counterpoint. In: NAGY-ZEKMI, S. (ed.), Paradoxical Citizenship: Essays on Edward Said. Lexington: Lexington Books, pp. 67-74.

MAIKEY, H. (2017). Why we should boycott Gay Pride Tel Aviv. Newsweek 14 June 2017.

MARCEL, G. (1965). Being and Having: An Existentialist Diary. New York: Harper \& Row.

MAROM, Y. (2017). Anti-occupation LGBTQ activists block Tel Aviv pride parade. +972 Magazine. $9^{\text {th }}$ June 2017. https://www.972mag.com/anti-occupation-lgbtq-activistsblock-tel-aviv-pride-parade/

MARTIN, B. (1996). Femininity Played Straight: The Significance of Being Lesbian. New York: Routledge.

MILANI, T. M. (2019). Queer performativity. In: HALL, K.; BARRETT, R. (eds), The Oxford Handbook of Language and Sexuality. Oxford: Oxford University Press. https:// 
www.oxfordhandbooks.com/view/10.1093/oxfordhb/9780190212926.001.0001/ oxfordhb-9780190212926-e-15

MILANI, T. M.; LEVON, E. (2016). Sexing diversity: Linguistic landscapes of homonationalism. Language and Communication. v. 51, pp. 69-86.

MILANI, T. M.; LEVON, E.; GAFTER, R. J.; OR, I. G. (2018). Tel Aviv as a space of affirmation versus transformation: Language, citizenship, and the politics of sexuality in Israel. Linguistic Landscapes. v. 43, pp. 278-297.

MILANI, T. M.; RICHARDSON, J. E. (eds) (in press). Discourse and Affect. Special issue of Social Semiotics.

MISGAV, C.; HARTAL, G. (eds) (2019a). Queer Urban Movements: Activism and Politics in Contemporary Contexts. Special issue of Geograpby Research Forum. v. 39.

MISGAV, C.; HARTAL, G. (2019b). Queer urban movements from the margin(s)Activism, politics, space: An editorial introduction. Geography Research Forum. v. 39, pp. $1-18$.

MISGAV, C.; HARTAL, G. (2019c). Queer urban movements in Tel Aviv and Jerusalem: A comparative discussion. In: YACOBI, H.; NASASRA, M. (eds), Routledge Handbook on Middle Eastern Cities. London: Routledge, pp. 57-74.

MOTSCHENBACHER, H. (2020). Walking on Wilton Drive: A linguistic landscape analysis of a homonormative space. Language and Communication. v. 72, pp. 25-43.

MPENDUKANA, S.; STROUD, C. (2019). Of monkeys, shacks and loos: Changing times, changing places. In: PECK, A.; STROUD, C.; WILLIAMS, Q. E. (eds), Making Sense of People and Place in Linguistic Landscapes. London: Bloomsbury, pp. 183-200.

MSIBI, T. (2014). Is current theorising on same-sex sexuality relevant to the African context? Pambazuka News bttps://www.pambazuka.org/governance/current-theorising-same-sexsexuality-relevant-african-context

MUÑNZ, J. E. (2009). Cruising Utopia: The Then and There of Queer Futurity. New York: NYU Press.

MURRAY, D. A. B. (ed.) (2014). Queering Borders: Language, Sexuality and Migration. Special issue of Journal of Language and Sexuality. v. $3, \mathrm{n}^{\circ} 1$. 
PENNYCOOK, A. (2012). Language and Mobility - Unexpected Places. Clevedon: Multilingual Matters.

OOSTENDORP, M. (in press). Linguistic citizenship and non-citizens: Of utopias and dystopias. In: WILLIAMS, Q. E.; DEUMERT, A.; MILANI, T. M. (eds), Linguistic Citizenship. Clevedon: Multilingual Matters.

OTSUJI, E.; PENNYCOOK, A. (2010). Metrolingualism: Fixity, fluidity and language in flux. International Journal of Multilingualism. v. 7, n 3 , pp. 240-254.

PUAR, J. (2007). Terrorist Assemblages. Raleigh: Duke University Press.

PUAR, J. (2017). The Right to Maim: Debility, Capacity, Disability. Raleigh: Duke University Press.

RITCHIE, J. (2010). How do you say "come out of the closet" in Arabic? Queer activism and the politics of visibility in Israel-Palestine. GLQ. vol. 16, $n^{\circ} 4$, pp. 557-575.

RITCHIE, J. (2011). Queer Checkpoints: Sexuality, Survival, and the Paradoxes of Sovereignty in IsraelPalestine. PhD thesis. The University of Illinois Urbana-Champaign.

SAID, E. (1994). Culture and Imperialism. London: Vintage.

SAID, E. (2000 [1984]). Reflections on exile. In: SAID, E. (ed.) Reflections on Exile and Other Essays. Cambridge: Harvard University Press, pp. 137-149.

SCOLLON, R.; SCOLLON, S. W. (2003). Discourses in Place: Language in the Material World. London: Routledge.

STROUD, C. (2001). African mother-tongue programmes and the politics of language: Linguistic citizenship versus Linguistic Human Rights. Journal of Multilingual and Multicultural Development. v. 22, $\mathrm{n}^{\circ} 4$, pp. 339-355.

STROUD, C. (2009). Towards a postliberal theory of citizenship. In: PETROVIC, J. (ed.), International perspectives on bilingual education: Policy, practice and controversy. New York: Information Age Publishing, pp. 191-218.

STROUD, C. (2015). Linguistic citizenship as utopia. Multilingual Margins. v. 2, n 2, pp. 20-37.

STROUD, C. (2018). Linguistic citizenship. In: LIM, L.; STROUD, C.; WEE, L. (eds), The Multilingual Citizen. Clevedon: Multilingual Matters, pp. 17-39. 
STROUD, C.; WILLIAMS, Q. E. (2017). Multilingualism as utopia: Fashioning non-racial selves. AILA Review. v. 30, pp. 167-188.

URICH, B.; BIELEN, K. (2007). The Words and Music of Jobn Lennon. Westport: Praeger.

WALDMAN, K. (2015). Why do we always turn to John Lennon's "Imagine" after a violent tragedy? Slate $18^{\text {th }}$ November 2015 https://slate.com/culture/2015/11/imaginewhy-do-we-always-turn-to-john-lennons-best-known-song-after-a-violent-tragedy. html

WARNER, M. (1993). Introduction. In: WARNER, M. (ed.), Fear of a Queer Planet. Minneapolis: University of Minnesota Press, pp. vii-xliv.

WEIZMAN, E. (2007). Hollow Land: Israel's Architecture of Occupation. London: Verso.

WIEGMAN, R.; WILSON, E. A. (2015). Introduction: Antinormativity's queer conventions. differences: A Journal of Feminist Cultural Studies. v. 26, $n^{\circ} 1$, pp. 1-25.

ZIV, A. (2010). Performative politics in Israeli queer anti-occupation activism. GLQ. V26, $\mathrm{n}^{\circ} 4$, pp. 537-556.

Recebido: 27/8/2020

Aceito: 17/11/2020

Publicado: 23/11/2020 